\title{
KATEGORI PERTANYAAN PADA UJIAN TUGAS AKHIR SKRIPSI
}

\author{
Dwiyanto Djoko Pranowo dan Roswita Lumban Tobing \\ Fakultas Bahasa dan Seni Universitas Negeri Yogyakarta \\ email: dwiyanto@uny.ac.id.
}

\begin{abstract}
Abstrak
Upaya peningkatan kualitas suatu program perlu dukungan data tingkat capaian secara periodik melalui evaluasi. Evaluasi diperlukan agar kualitas proses dan hasil dapat ditingkatkan. Penelitian ini bertujuan untuk mendeskripsikan pelaksanaan ujian Tugas Akhir Skripsi dan mengkategorisasikan pertanyaan-pertanyaan dalam tes lisan. Penelitian ini merupakan penelitian survei. Subjek penelitian adalah mahasiswa Jurusan Pendidikan Bahasa Prancis, Fakultas Bahasa dan Seni, Universitas Negeri Yogyakarta, yang menempuh ujian pada lima tahun terakhir (2012 - 2017). Teknik pengumpulan data menggunakan dokumentasi dan angket. Data dianalisis menggunakan teknik deskriptif kuantitatif dan kualitatif. Hasil penelitan sebagai berikut. Pertama, ujian lisan yang dilaksanakan selama 60-90 menit dengan tiga anggota tim penguji terbagi dalam tiga bidang kajian skripsi, yaitu: (1) inguistik, (2) sastra, dan (3) pengajaran. Kedua, pertanyaan-pertanyaan terpetakan dalam lima kategori dan 14 sub-kategori, yaitu pertanyaan: (1) terbuka-tertutup, (2) teknis-substantif, (3) berdasar tingkat kognitif (mengingat, memahami, menerapkan, menganalisis, mengevaluasi, dan mencipta), (4) klarifikasi-pendalaman-perluasan, dan (5) di luar naskah skripsi.
\end{abstract}

Kata kunci: tes lisan, skripsi, kategori pertanyaan

\section{CATEGORIES OF QUESTIONS \\ IN THE UNDERGRADUATE THESIS EXAMINATION}

\begin{abstract}
Efforts to improve the quality of a program need to be supported by data on the periodic achievement levels through evaluation. Evaluation is necessary to improve the quality of the process and outcomes. This study aims to describe undergraduate thesis examinations and to categorize examination questions. This was a survey study. The subjects were students of the French Language Department, Faculty of Languages of Arts, Yogyakarta State University, sitting for the examinations in the last five years (2012-2017). The data were collected using documentation and questionnaires. They were analyzed by means of quantitative and qualitative descriptive techniques. The findings are as follows. First, an undergraduate thesis examination is conducted for 60-90 minutes with three examiners and there are three fields of study, namely: (1) linguistics, (2) literature, and (3) teaching. Second, questions are classified into five categories and 14 sub-categories, namely: (1) open and closed ended; (2) technical and substantive; (3) cognitive-level-based (remembering, understanding, implementing,
\end{abstract}


analyzing, evaluating, and creating); (4) clarifying, probing, and extending; and (5) out-of-script questions.

Keywords: examination, undergraduate thesis, categories of questions

\section{PENDAHULUAN}

Peraturan Akademik Universitas Negeri Yogyakarta tahun 2014, mewajibkan mahasiswa program S1 menyusun tugas akhir berbentuk Tugas Akhir Skripsi (TAS) sebagai syarat akhir studi. Pelaksanaan tugas akhir mengacu pada Pedoman Tugas Akhir UNY. Tugas akhir adalah karya tulis mahasiswa yang merupakan hasil proses berfikir ilmiah, kreatif, integratif, dan sesuai dengan disiplin ilmunya yang disusun untuk memenuhi persyaratan kebulatan studi dalam program dan jenjang pendidikan yang ada di lingkungan UNY. Tugas akhir tersebut harus dipertanggungjawabkan di depan dewan penguji dalam bentuk ujian skripsi.

Ujian skripsi dilaksanakan secara lisan oleh 3-4 orang penguji, yang terdiri dari ketua penguji (pembimbing), sekretaris, penguji utama dan penguji pendamping. Waktu pelaksanaan ujian 60 - 90 menit. Penilaian didasarkan pada dua kategori, yaitu penilaian dokumen dan penilain ujian lisan. Dalam evaluasi, tes lisan termasuk dalam jenis tes subjektif yang tidak dapat lepas dari subjektivitas evaluatornya. Rendahnya objektivitas sebuah tes berpotensi bias pada hasil pengukurannya.

Ada tiga aspek yang dinilai dalam pelaksanaan ujian lisan sesuai dengan lembar penilaian yang dirumuskan dalam lembar penilaian, yaitu 1) Kemampuan mengungkapkan/menguraikan Pendapat, 2) Ketepatan/Relevensi jawaban dengan pertanyaan, dan 3) Penguasaan Materi Skripsi. Menurut pengamatan peneliti para evaluator tidak dibekali dengan kriteria yang jelas tentang standar penilaian (rubrik). Hal ini berpotensi ketidakkonsistenan evaluator dalam memberi skor terhadap jawaban tertes.

Untuk meningkatkan kualitas pelaksanaan ujian skripsi perlu adanya evaluasi secara periodik. Upaya peningkatan kualitas suatu program perlu dukungan data tingkat capaian secara periodik melalui kegiatan yang dikenal dengan evaluasi. Dalam berbagai program kehadiran evaluasi selalu diperlukan agar kualitas proses dan output dapat selalu ditingkatkan. Oleh karena itu Peneliti ingin mengetahui pelaksanaan ujian Tugas Akhir Skripsi dan kualitas penilaiannya di Jurusan Pendidikan Bahasa Prancis lima tahun terakhir.

Berangkat dari uraian diatas maka permasalahan yang diangkat dalam penelitian ini adalah:

1. Bagaimanakah mekanisme pelaksanaan ujian tugas akhir skripsi di Jurusan Pendidikan Bahasa Perancis?

2. Apasajakah jenis-jenis pertanyaan yang diajukan oleh dewan penguji tugas akhir skripsi?

3. Jenis pertanyaan apakah yang palingsering diajukan dalam proses ujian lisan skripsi?

Secara umum tujuan penelitian ini adalah untuk mendeskripsikan proses pelaksanaan ujian, mengetahui jenisjenis pertanyaan yang muncul, dan 
mengetahui frekuensi pertanyaan yang paling sering diajukan oleh dewan penguji tugas akhir skripsi. Hasil temuannya dapat merefleksikan kualitas kedalaman dan keluasan pertanyaan yang diajukan dalam ujian lisan skripsi.

\section{METODE}

Penelitian deskripsi evaluatif ini merupakan penelitian studi kasus yang target sasarannya adalah mengevaluasi pelaksanaan suatu program kegiatan. Subjek penelitian dosen penguji skripsi di jurusan Pendidikan Bahasa Prancis, FBS UNY dan mahasiswa telah menempuh ujian skripsi tahun 2012-2017. Sumber datanya adalah dokumen yang berupa berita acara ujian dan catatan pelaksanaan ujian skripsi. Sementara itu, objek dalam penelitian ini adalah proses pelaksaaan ujian lisan dan soal ujian lisan yang akan dianalisis jenisjenis pertanyaan yang muncul selama proses ujian.

Angket digunakan untuk mengungkap secara deskriptif pelaksanaan ujian dalam upaya peningkatan kualitas ujian tugas akhir mahasiswa. Teknik pengumpulan data dilakukan berdasarkan tujuan penelitian yaitu melalui dokumentasi. Dokumentasi berupa hasil catatan pelaksanaan ujian yang terdokumentasi di kantor bagian akademik Fakultas Bahasa dan Seni Universitas Negeri Yogyakarta.

Angket dikembangkan berdasarkan kisi-kisi sebagai berikut.

Tabel 1. Kisi-Kisi Angket

\begin{tabular}{|c|c|c|}
\hline No & Aspek & Indikator \\
\hline 1 & 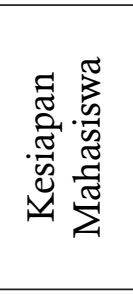 & $\begin{array}{l}\text { 1. kesiapan materi } \\
\text { 2. kesiapan mental } \\
\text { 3. kesiapan fisik } \\
\text { 4. tingkat pemahaman pertanyaan } \\
\text { 5. kesesuaian hasil dan pertanyaan } \\
\text { 6. kepuasan terhadap hasil }\end{array}$ \\
\hline 2 & 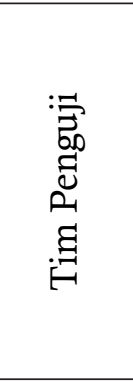 & $\begin{array}{l}\text { 1. sikap penguji } \\
\text { 2. kesiapan penguji } \\
\text { 3. cara mengajukan pertanyaan } \\
\text { 4. kejelasan pertanyaan } \\
\text { 5. relevansi pertanyaan dan isi } \\
\text { 6. proporsi teknis - substantive } \\
\text { 7. proporsi substantif - resume } \\
\text { 8. proporsi substantif - saran }\end{array}$ \\
\hline 3 & $\begin{array}{l}\mathbb{Z} \\
\text { त्ञ్జ } \\
\text { 心 }\end{array}$ & $\begin{array}{l}\text { 1. alokasi waktu ujian } \\
\text { 2. proporsi waktur antar penguji } \\
\text { 3. kenyamanan ruang \& lingkungan } \\
\text { 4. kesediaan sarana audio-visual } \\
\text { 5. kesigapan petugas ruang }\end{array}$ \\
\hline
\end{tabular}


Dokumen proses pelaksanaan ujian berisi tentang tim penguji dan daftar pertanyaan yang diajukan oleh masingmasing penguji. Data pertanyaan diklasifikasi berdasarkan 5 kategori, yaitu yaitu 1) Bentuk pertanyaan terbuka/ tertutup, 2) pertanyaan bersifat teknis/ substantif, 3) pertanyaan yang mendasarkan pada rantai kognitif taksonomi Bloom versi revisi (ingatan, pemahaman, penerapan, analisis, penerapan, penciptaan/ kreasi), 4) pertanyaan yang bersifat klarifikasi dan pertanyaan penyelidikan (pendalaman/perluasan) 5) pertanyaan yang tidak terkait langsung dengan naskah skripsi. Contoh pertanyaan untuk masing-masing tingkatan kognitif Bloom adalah sebagai berikut.

a. Pada tingkatan berpikir mengingat: Apa rumusan masalah dalam penelitian Saudara?

b. Pada tingkatan berpikir memahami: Mengapa Saudara mengangkat masalah tersebut dalam penelitian?

c. Pada tingkatan berpikir menerapkan:

Coba Saudara tunjukan cara mensekor hasil pekerjaan responden?

d. Pada tingkatan berpikir menganalisis:

Jelaskan apa yang mendasari Saudara mengambil simpulan dari data tersebut?

e. Pada tingkatan berpikir mengevaluasi:

Apakah menurut saudara pertanyaan-pertanyaan yang Saudara ajukan pada responden tidak bias? Mengapa?

f. Pada tingkatan berpikir Mengkreasi:

Buatlah hipotesis tindakan untuk siklus kedua berdasarkan hasil refleksi pada siklus pertama!.
Kelima kategori pertanyaan yang dijabarkan dalam 14 subkategori tersebut implementasinya dilengkapi dengan kriteria analisis data yang berupa katakata kunci dalam menjakukan pertanyaan oleh penguji.

\section{HASIL DAN PEMBAHASAN Hasil}

Skripsi adalah karya tulis ilmiah mahasiswa yang merupakan kulminasi proses berpikir ilmiah sesuai dengan disiplin ilmunya, yang disusun untuk memenuhi persyaratan memperoleh gelar sarjana dalam program dan jenjang pendidikan S1 di UNY. Penyusunan skripsi bertujuan memantapkan wawasan pengetahuan dan pengalaman mahasiswa dalam melakukan kegiatan ilmiah, dengan cara memberi kesempatan memformulasikan ide, konsep, pola berpikir, dan kreativitas yang dikemas secara komprehensif, dan mengkomunikasikan dalam format yang lazim digunakan di kalangan masyarakat ilmiah.

Mahasiswa yang berhak mengajukan usulan penyusunan skripsi harus memenuhi persyaratan sebagai berikut.

a. Telah menyelesaikan sekurangkurangnya 110 sks.

b. Indeks Prestasi Kumulatif (IPK) sekurang-kurangnya 2,50.

c. Mendapat rekomendasi dari Penasehat Akademik.

Ujian skripsi berlangsung antara 60 menit s.d 1.20 menit secara terbuka dengan pembagian waktu sebagai berikut.

a. Ketua Tim Penguji membuka sidang setelah pengecekan persyaratan administrasi dilakukan.

b. Teruji menyampaikan ringkasan skripsi secara lisan 5 -7 menit 
c. Penguji utama mengajukan pertanyaan dengan waktu $30-40$ menit

d. Dilanjutkan sekretaris mengajukan pertanyaan dengan alokasi waktu 10-15 menit

e. Ketua mengajukan pertanyaan dengan alokasi waktu 10-15 menit.

f. Tim penguji bersidang untuk menentukan nilai akhir ujian dengan mempersilakan peserta ujian mau- pun penonton untuk meninggalkan ruang ujian.

g. Sekretaris penguji merekap hasil penilaian tim penguji.

h. Ketua tim penguji mengumumkan hasil ujian.

i. Ketua menutup sidang.

Sedangkan format penyekorannya menggunakan tabel 2 berikut ini.

\section{Tabel 2. Format Penilaian Ujian TAS}

\begin{tabular}{|c|c|c|c|c|}
\hline No & BUTIR YANG DINILAI & BOBOT NILAI & SKOR & NILAI \\
\hline \multicolumn{5}{|c|}{ PENILAIAN DOKUMEN TAS } \\
\hline 1 & Bagian Pendahuluan & 15 & & \\
\hline 2 & Bagian Teori & 10 & & \\
\hline 3 & Bagian Metode Penelitian & 10 & & \\
\hline 4 & Bagian Hasil Penelitian dan Pembahasan & 15 & & \\
\hline 5 & Bagian Penutup (Kesimpulan \& Saran) & 5 & & \\
\hline 6 & Teknik Penulisan & 5 & & \\
\hline 7 & Intisari (Resume berbhs Prancis) & 10 & & \\
\hline \multicolumn{5}{|c|}{ PENILAIAN UJIAN LISAN } \\
\hline 1 & $\begin{array}{l}\text { Kemampuanmengungkapkan/ } \\
\text { menguraikan Pendapat }\end{array}$ & 10 & & \\
\hline 2 & $\begin{array}{l}\text { Ketepatan/Relevensi jawaban dengan } \\
\text { pertanyaan }\end{array}$ & 10 & & \\
\hline 3 & Penguasaan Materi Skripsi & 10 & & \\
\hline
\end{tabular}

Data dalam bentuk kalimat tanya yang berada di notulen pelaksanaan ujian skripsi teridentifikasi dengan sebaran sebagai tabel 3 berikut.

\section{Tabel 3. Data Jumlah Pertanyaan}

\begin{tabular}{clcc}
\hline No & Kelompok & Jumlah & Persentase \\
\hline 1 & Linguistik & 313 & 36,60 \\
2 & Pengajaran & 262 & 30,64 \\
3 & Sastra & 280 & 32,74 \\
\hline \multicolumn{3}{r}{ Jumlah } & 855 \\
\hline
\end{tabular}

Terdapat 855 pertanyaan yang berasal dari kelompok ujian skripsi bidang linguistik, pengajaran, dan sastra. Pertanyaan-pertanyaan tersebut dapat dipetakan dalam berbagai kategori, yaitu 1) terbuka-tertutup, 2) teknis-substantif, 3) C1-C6 (ingatan, pemahaman, penerapan, analisis, penerapan, penciptaan), 4) klarifikasi-pendalaman-perluasan 5) di luar naskah skripsi. Hasil identifikasi data dilihat pada tabel 4 . 
Tabel 4. Data Jenis Pertanyaan

\begin{tabular}{clcccc}
\hline No & Type of Question & $\begin{array}{c}\text { Linguistic } \\
(\mathbf{\%})\end{array}$ & $\begin{array}{c}\text { Teaching } \\
\mathbf{( \% )}\end{array}$ & $\begin{array}{c}\text { Literature } \\
\mathbf{( \% )}\end{array}$ & $\begin{array}{c}\text { SUM } \\
\mathbf{( \% )}\end{array}$ \\
\hline 1 & Open & 73,2 & 52,7 & 47,9 & 58,6 \\
2 & closed & 4,2 & 31,3 & 42,2 & 24,9 \\
3 & Technical & 26,8 & 34,4 & 33,6 & 31,4 \\
4 & Substantif & 55,9 & 48,1 & 64,6 & 56,4 \\
5 & Remembering & 5,4 & 10,7 & 6,1 & 7,3 \\
6 & Understanding & 23,3 & 17,9 & 48,6 & 29,9 \\
7 & Applying & 17,9 & 29,4 & 13,9 & 20,2 \\
8 & Analyzing & 9,6 & 16,4 & 11,1 & 12,2 \\
9 & Evaluating & 9 & 3,1 & 7,2 & 6,6 \\
10 & Creating & 2,6 & 3,1 & 0,7 & 2,1 \\
11 & Clarifying & 65,2 & 65,7 & 49,3 & 60,1 \\
12 & deepening & 25,9 & 26,4 & 44,3 & 32,1 \\
13 & widening & 2,9 & 5,4 & 3,9 & 4 \\
14 & irrelevant & 1,3 & 2,7 & 0,00 & 1,3 \\
\hline
\end{tabular}

\section{Pembahasan}

Proses pelaksanaan ujian tugas akhir skripsi telah berjalan sesuai dengan aturan pelaksanaan yang tertuang dalam buku panduan penulisan tugas akhir yang diterbitkan oleh Fakultas Bahasa dan seni. Penilaian mahasiswa terhadap pelaksanaan ujian rata-rata 3,52 dari skor maksimal 4 yang berarti dalam kategori sangat baik. Ini berarti bahwa rata-rata mahasiswa sangat siap dalam mengikuti ujian skripsi. Tim pengujipun dinilai bersikap baik, mengajukan pertanyan dengan jelas dan proporsional sesuai dengan tugas masing-masing penguji.

\section{Pertanyaan terbuka dan tertutup}

Bentuk pertanyaan dapat dibedakan atas dua pertanyaan, yaitu pertanyaan terbuka dan pertanyaan tertutup. Perbedaan keduanya adalah pada tingkat kebebasan responden dalam menjawab pertanyaan. Pertanyaan terbuka memungkinkan responden mem- berikan jawaban yang dikehendakinya dengan kata-kata yang dipilihnya sendiri. Sedangkan pertanyaan tertutup membatasi jawaban responden dengan keharusan diantara jawaban-jawaban yang sudah tercantum dalam kusioner. Ashari (2017). Pertanyaan yang menuntut jawaban "ya-tidak" termasuk contoh dari pertanyaan tertutup

Ditinjau dari sifatnya, bahwa ujian skripsi adalah ujian lisan yang berbentuk tanya jawab, maka ini sejalan dengan data ditemukan bahwa 58,60\% atau sebagian besar pertanyaan bersifat pertanyaan terbuka. Sedangkan pertanyaan tertutup hanya $24,51 \%$ seperti terlihat pada tabel 5 berikut. Hal ini berarti bahwa pertanyaan-pertanyaan yang diajukan tidak sekedar pertanyaan YA-TIDAK, tetapi lebih banyak pertanyaan-pertanyaan yang menuntut jawaban yang disertai dengan penjelasan yang panjang. 
Tabel 5. Pertanyaan berdasarkan sifatnya

\begin{tabular}{clcc}
\hline No & $\begin{array}{c}\text { Jenis } \\
\text { Pertanyaan }\end{array}$ & Jumlah & \% \\
\hline 1 & $\begin{array}{l}\text { Terbuka } \\
\text { (Divergen) } \\
2\end{array}$ & 501 & 58,60 \\
& $\begin{array}{l}\text { Tertutup } \\
\text { (Konvergen) }\end{array}$ & 213 & 24,91 \\
\hline & Jumlah & 714 & 83,51 \\
\hline
\end{tabular}

\section{Pertanyaan Teknis dan substantif}

Dari sudut pandang fokus pertanyaan, penguji dapat mengajukan pertanyaan-pertanyaan yang terkait dengan teknis tata tulis karya ilmiah maupun substansi objek kajian yang dibahas dalam karya ilmiah yang diujikan. Pertanyan-pertanyaan tentang tata tulis, tata letak, ejaan, kalimat, cara menuliskan referensi, dan sejenisnya adalah contoh dari pertanyaan yang terfokus kepada teknis penulisan. Dari hasil identifikasi dan klasifikasi tentang fokus pertanyaan, dapat terlihat pada gambar diagram 1 berikut ini.

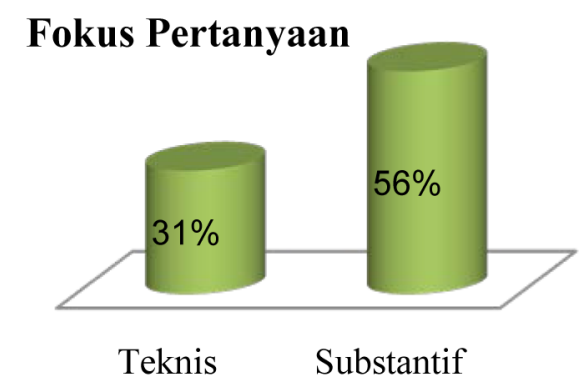

\section{Gambar 1. Pertanyaan berdasarkan Fokus}

Dari gambar diagram 1 terlihat jelas bahwa persentase pertanyaan subtantif (56\%) lebih besar dari pertanyaan teknis (31\%). Dalam kenyataan dilapangan, banyak koreksi tata tulis pada naskah skripsi mahasiswa. Namun mayoritas penguji memberi koreksi sebagai masukan langsung dalam naskah sehingga waktu yang tersedia dimanfaatkan oleh penguji untuk mengajukan pertanyaanpertanyaan yang lebih substantif.

Dilihat dari koreksi tata tulis yang tuntas dalam naskah, secara implisit menyiratkan bahwa penguji membaca secara tuntas naskah skripsi yang sebagaimana tertera dalam standar operasional baku (SOP) pendaftaran ujian bahwa naskah skripsi harus diserahkan kepada penguji satu minggu sebelum pelaksanaan ujian.

\section{Pertanyaan Berdasarkan Taksonomi Bloom}

Dalam versi revisi taksonomi Bloom melakukan pemisahan antara dimensi pengetahuan (knowledge) dan dimensi proses kognitif. Dimensi pengetahuan mencakup pengetahuan faktual, pengetahuan konseptual, pengetahuan prosedural dan pengetahuan metakognitif. Dimensi proses kognitif yang digunakan sebagai dasar klasifikasi pertanyaan, mencakup menghafal (remembering), memahami (understandding), menerapkan (applying), menganalisis (analysing), mengevaluasi (evaluating), dan membuat (creating). (Anderson et al., 2001)

Dari data kalimat tanya yang terkumpul, terdapat sejumlah 668 kalimat yang dapat diklasifikasikan dalam 7 kategori berdasarkan taksonomi Bloom. Dari jumlah tersebut persentase terbesar pada pertanyaan tingkat pemahaman seperti yang terpapar pada gambar 2 berikut ini. 


\section{Jumlah pertanyaan}

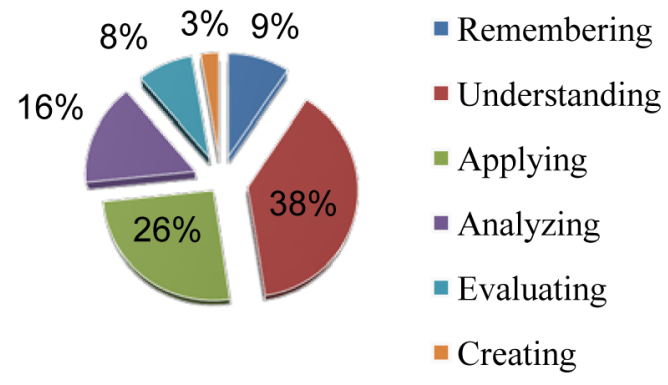

Gambar 2. Pertanyaan berdasarkan Tingkatan Kognitif

Tingkatan taksonomi Bloom disusun berdasar peringkat tingkat kesulitas dari yang paling rendah (remembering) sampai yang paling tinggi atau palingkomplek (creating). Pertanyan-pertanyaan yang mengungkap hal-hal yang faktual yang jawabannya mendasarkan pada hafalan atau daya ingat dalam klasifikasi Bloom dinyatakan sebagai tingkat kognitif paling dasar. Seseorang yang memiliki posisi kognisi pada level ini dianggap sebagai seseorang yang baru mengenal fakta/konsep tetapi belum paham tentang fakta tersebut apalagi menganalisis menggunakan konsep tersebut. Tingkat kognisi paling tinggi adalah berkarya (creating). Apabila sudah mampu mengkreasi sesuai yang baru berdasarkan konsep yang dipelajari, maka seseorang dianggap telah memiliki kemampuan berpikir tingkat tertinggi.

Gambar 2 menunjukan bahwa ada $38 \%$ pertanyaan berada pada klasifikasi tingkat pemahaman. $26 \%$ pada level 3 yaitu kemampuan menerapkan (applying). Bila digabung kedua level tersebut berarti $64 \%$ pertanyaan tingkat kompleksitasnya ada pada menengah kebawah. Hal ini berarti pertanyaanpertanyaan yang diajukan oleh penguji sebagian besar masih bersifat low order thinking (LOT) dan hanya sebagian kecil yang menuntut high order thinking (HOT)

\section{Pertanyaan klarifikatif, pendalaman dan perluasan}

Tujuan mengajukan pertanyaan dapat diklasifikasikan menjadi dua, yaitu untuk mengklarifikasi dan pertanyaan untuk menyelidiki (memperdalam dan memperluas permasalahan).

Indiana university (2017) menuliskan bahwa "Clarifying Questions are simple questions of fact. They clarify the dilemma and provide the nuts and bolts so that the participants can ask good probing questions and provide useful feedback". Contoh dari pertanyaan untuk klarifikasi ini adalah:

- Sumber apa yang Anda gunakan dalam penelitian ini?

- Apakah Saudara paham dengan apa yang Anda nyatakan itu?

Sementara itu pertanyaan yang bertujuan untuk menyelidik (probing) dapat bersifat memperdalam (menggali) atau memperluas permasalahan. "Probing Questions are intended to help the presenter think more deeply about the issue at hand". Contoh dari pertanyaan menyelidik ini adalah sebagai berikut.

- Bagaimana Anda menyimpulkan dari dari kasus tersebut?

- Apa dampak dari penelitian ini?

Gambar 3 berikut menampilkan data tentang tujuan pertanyaan yang diajukan oleh tim penguji tugas akhir skripsi. Sebagian besar (63\%) berupa pertanyaan yang bertujuan untuk mengklarifikasi apa yang telah dilakukan dan ditulis oleh mahasiswa. 


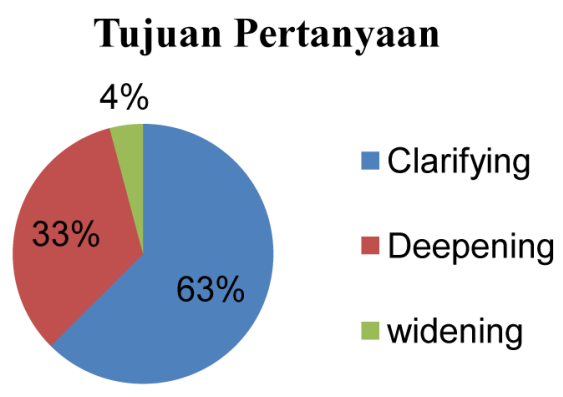

\section{Gambar 3. Pertanyaan berdasarkan Tujuannya}

Namun ada $37 \%$ pertanyaan yang bertujuan untuk menyelidiki $33 \%$ memperdalam permasalahan dan 4\% memperluas). Persentase ini cukup ideal untuk tingkat ujian skripsi. Hal ini sejalan dengan tujuan ujian lisan tugas akhir skripsi seperti yang tertuang dalam lembar evaluasi ujian yaitu mengungkap 3 hal, yaitu 1) Kemampuan mengungkapkan/menguraikan Pendapat, 2) Ketepatan/Relevensi jawaban dengan pertanyaan, dan 3) Penguasaan Materi Skripsi. Masing-masing indikator berbobot 10. Dalam lembar evaluasi ada dua komponen yang dinilai, yaitu dokumen tugas akhir dengan bobot $70 \%$, dan penilaian ujian lisan dengan bobot $30 \%$.

\section{Pertanyaan diluar naskah skripsi}

Dalam proses ujian ada kemungkinan penguji mengajukan pertanyaan di luar dokumen TAS. Dari penelitian ditemukan bahwa dari 855 pertanyaan ada 11 pertanyaan $(1,3 \%)$ yang masuk dalam kategori irrelevant to the script. Persentase ini sangat kecil sehingga keberadaan indikator ini dapat diabaikan. Artinya dapat disimpulkan bahwa semua pertanyaan yang diajukan relefan dengan dokumen tugas akhir skripsi yang diujikan.

\section{SIMPULAN}

Mekanisme pelaksanaan ujian lisan sudah sesuai dengan aturan baku pedoman pelaksanaan ujian yang dikeluarkan oleh Fakultas Bahasa dan Seni UNY yang termuat dalam buku pedoman penulisan tugas akhir.

Jenis-jenis pertanyaan yang diajukan oleh dewan penguji tugas akhir skripsi terklasifikasikan dalam lima kategori, yaitu 1) berdasarkan sifat pertanyaan, 2) berdasarkan fokus, 3) berdasarkan taksonomi Bloom, 4) berdasarkan tujuannya, dan 5) berdasarkan relevansi terhadap naskah skripsi.

Jenis pertanyaan yang paling sering diajukan dalam proses ujian lisan skripsi adalah 1) pertanyaan terbuka, 2) pertanyaan fokus pada substantif, 3) mayoritas pertanyaan pemahaman, 4) bertujuan untuk mengklarifikasi, dan tidak ada pertanyaan yang menyimpang dari dokumen tugas akhir skripsi.

\section{UCAPAN TERIMAKASIH}

Ucapan terima kasih disampaikan kepada seluruh narasumber dan sejawat serta mahasiswa yang telah membantu penelitian dan penulisan hingga mewujud menjadi bentuk artikel ini. Harapannya, tulisan ini dapat bermanfaat bagi jurusan Pendidikan Bahasa Perancis UNY, khususnya dalam upaya menjaga dan meningkatkan kualitas sehingga dapat memberikan pelayanan terbaik pada mahasiswa.

\section{DAFTARPUSTAKA}

Anderson, Lorin W. 1989. The Effective Teacher. New York: McGraw-Hill Book Company.

Ashari Muhri.2017. Perancangan Kuesioner (Quetioner Design) Untuk Penelitian Karya Tulis Ilmiah. Sulsel:LPMP. 
Retrieved from http://lpmpsulsel. kemdikbud.go.id/tulisan-437
Indiana University. (2017). Deliberation for Global Perspectives in Teaching and Learning Step Two: Define. Retrieved from http://www.indiana. edu/ global/deliberation/Handouts/ 